- Science Foundation (NSF) and the Department of Energy (DOE) until three years ago, when the NSF halted funding. With staff cuts, he has been able to maintain operations with a budget of around $\$ 350,000$. He has also partnered with Earth Networks, an atmospheric-monitoring company based in Germantown, Maryland, which has deployed a sensor for him at Mauna Loa to reduce the costs for Scripps. His latest grant application to the DOE is pending, but in the meantime he is operating on spare funds.

The situation is murkier for the oxygen measurements, which the NSF and NOAA supported for more than two decades. The NSF pulled the plug in 2009, and Keeling's NOAA grant could run out in early January. In an effort to keep things going, Keeling says that he went back to the NSF and was assured that he would get about $\$ 350,000$ from the Division of Polar Programs this autumn. (NSF officials say that they cannot comment on pending grants.) That money would carry him into next year, but it remains unclear what will happen after that. Jim Butler, director of NOAA's Global Monitoring Division in Boulder, says that NOAA cannot simply fold Keeling's $\mathrm{CO}_{2}$ stations into its own observations budget, given that the value of having two $\mathrm{CO}_{2}$ networks is scientific independence. The oxygen measurements, by contrast, would fit nicely into NOAA's portfolio, Butler adds, but his division's budget has shrunk by $12 \%$ since 2011, with further cuts expected this fiscal year. Budget constraints have already forced the agency to reduce staff and shut down monitoring at ten sites.

"NOAA's budget is getting hammered, and it's increasingly difficult to fund things like Ralph's programme," Butler says. "All I can do right now is provide moral support to keep it going year by year until we come up with a plan."

For a while, it seemed that commercial interests might pick up some of the slack. Working with Scripps, Earth Networks announced plans in 2011 to deploy a global network of 100 greenhouse-gas monitoring stations. But two years later, with climate regulations on the back burner in Washington DC, the company is operating just 25 stations. "We really don't have any material customers at this point," says Earth Networks' president Bob Marshall.

Keeling has considered approaching private foundations for help, but acknowledges that atmospheric monitoring is an unusual target for philanthropy. Moreover, he says, a private donor would probably want to see evidence of stable government support before committing. "The difficulty of keeping these things going long term, even within the government, needs to be recognized," he says.

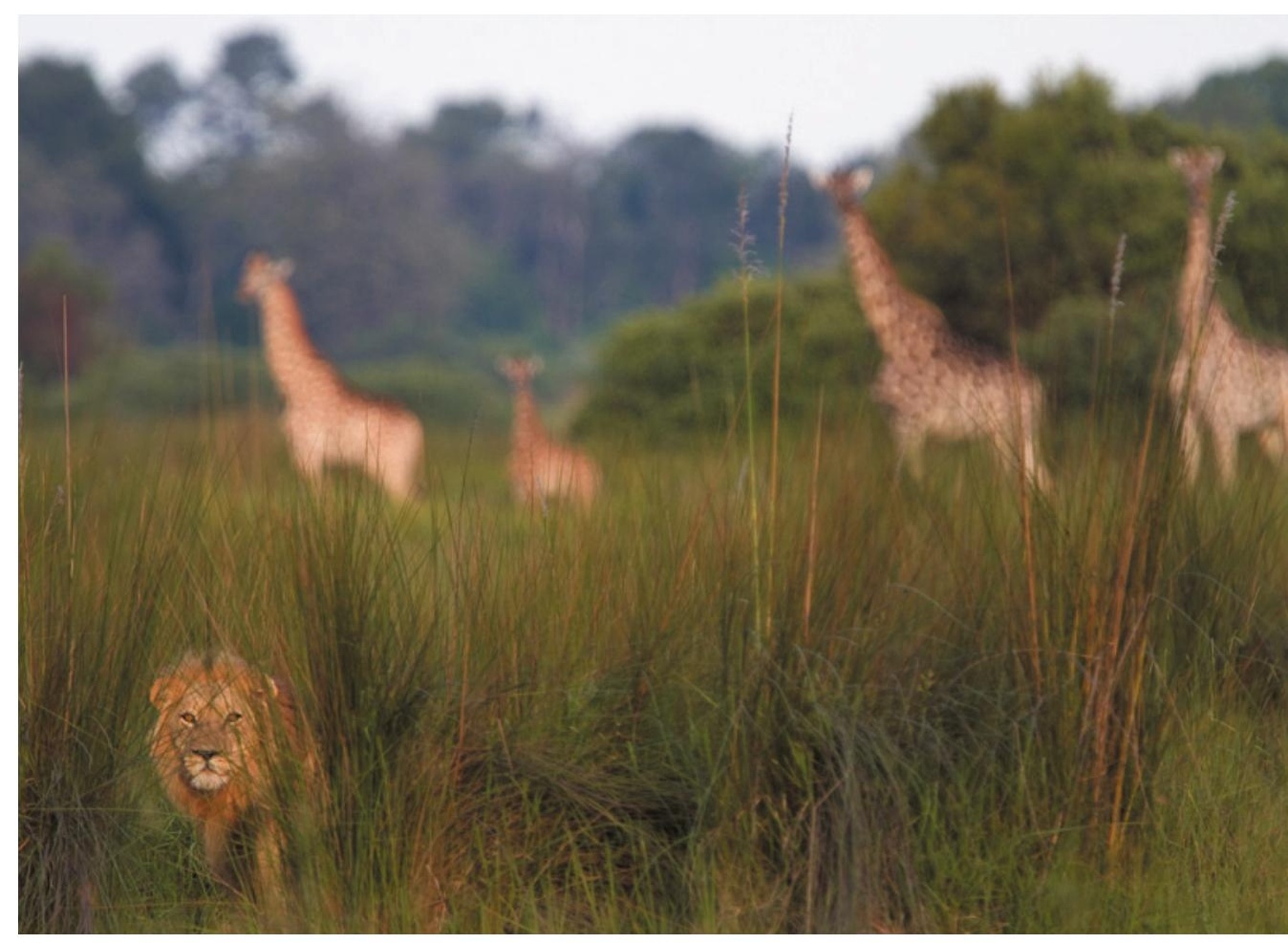

Lion numbers have fallen sharply in recent decades, in large part because of killing by humans.

\title{
ECOLOGY
}

\section{Fences divide lion conservationists}

\section{Some say enclosures offer protection, others maintain they are a menace.}

\section{BY TRACI WATSON}

$\mathrm{T}$ Times are grim for the king of the beasts. Roughly 35,000 African lions roam the savannahs ${ }^{1}$, down from more than 100,000 half a century ago, thanks to habitat loss, declining numbers of prey animals and killing by humans. One study estimated that fewer than 50 lions (Panthera leo) live in Nigeria and reported no sign of the animal in the Republic of the Congo, Ghana or Côte d'Ivoire $^{2}$.

Now a king-sized controversy is brewing over a proposal to shore up lion populations before it is too late. A prominent lion researcher has called for limiting conflict between humans and lions by erecting fences around reserves containing wild lions. The idea has split scientists, with those opposed to the idea arguing that fences could do more harm than good. The ensuing debate has also laid bare fundamental differences of opinion about how to preserve lions and other species, and raised concerns that a key challenge to lion conservation - lack of funds - is being ignored while scientists trade jabs about fences.

When he began the research that kicked

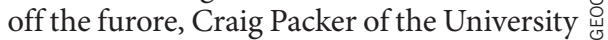
of Minnesota in St Paul, who studies lions at $\frac{\vec{z}}{2}$ Tanzania's Serengeti National Park, intended 을 to determine only the cost of conserving lions. But something more provocative emerged from his data. In work reported earlier this oे year in Ecology Letters $^{3}$, he and 57 co-authors calculated lion densities at 42 African reserves and found, Packer says, that the only variables that matter for density are "dollars and fence - nothing else". He adds that "the fence has a very profound, powerful effect", because it prevents lions from preying on livestock and people, meaning fewer lions are killed in retaliation. Packer would like to see fences around even some of the largest protected areas such as Tanzania's 47,000-square-kilometre Selous Game Reserve.

But the paper triggered heated discussion, 
both online and at meetings, leading four months later to the publication of a response signed by 55 researchers ${ }^{4}$. They argue that Packer's analysis is wrong to use lion population density as its sole yardstick. By that measurement, they say, a dense population of several dozen lions in a small reserve is a success, whereas a large reserve containing 600 lions is a failure. When the authors ${ }^{4}$ restricted their study to lion populations whose density did not exceed the land's capacity to support them and controlled for a reserve's management budget, they found no relationship between fencing and density.

That study's first author, Scott Creel of Montana State University in Bozeman, says that although fencing is beneficial at small, wellfunded reserves, most of Africa's wild lions live in large reserves with modest funding. "If you build a fence and spend a lot of money, you can maintain a lot of lions within it," Creel says. "The problem is, we don't know very much about how fencing works in enormous ecosystems that have smaller budgets."

Packer's side responded with its own reanalysis ${ }^{5}$. Rather than eliminating the supersaturated lion populations from the equation, the researchers assigned them a density of $100 \%$. Once again, they found the presence of fencing to be the strongest predictor of lion density, Packer says. Creel counters that the reanalysis shows no impact of fencing on population size, so it is still unclear whether fences would have a protective effect for large, natural ecosystems.

Other researchers are split over which argument is more convincing. Matt Hayward of Bangor University, UK, who co-authored a book about conservation fencing, says that both sides score points, and, in any case, the disagreement goes beyond statistics to "a very passionate philosophical debate". He adds that "some people are saying, 'Look, we don't want any fences in the landscape. We want to keep wildlife moving wherever it wants to."

And rightfully so, many say: ill-conceived fences could hinder animals' search for food during tough times, as well as leading to losses of wide-ranging species, such as cheetahs and wild dogs, that need big expanses of land. "Is saving lions above everything else?" asks Creel's co-author Nathalie Pettorelli of London's Institute of Zoology. "You cannot manage a landscape by looking at just one species."

\section{GROUNDS FOR CONCERN}

Researchers have divided the territories currently occupied by African lions into three categories, each indicating the big cats' predicted long-term success. About 24.000 lions live in strongholds, well-protected areas where their numbers are generally stable or increasing; 4,000/ive in potential strongholds, where their long-term chances are lower; and 6,000-plus animals live in other areas, where they are at greatest risk.

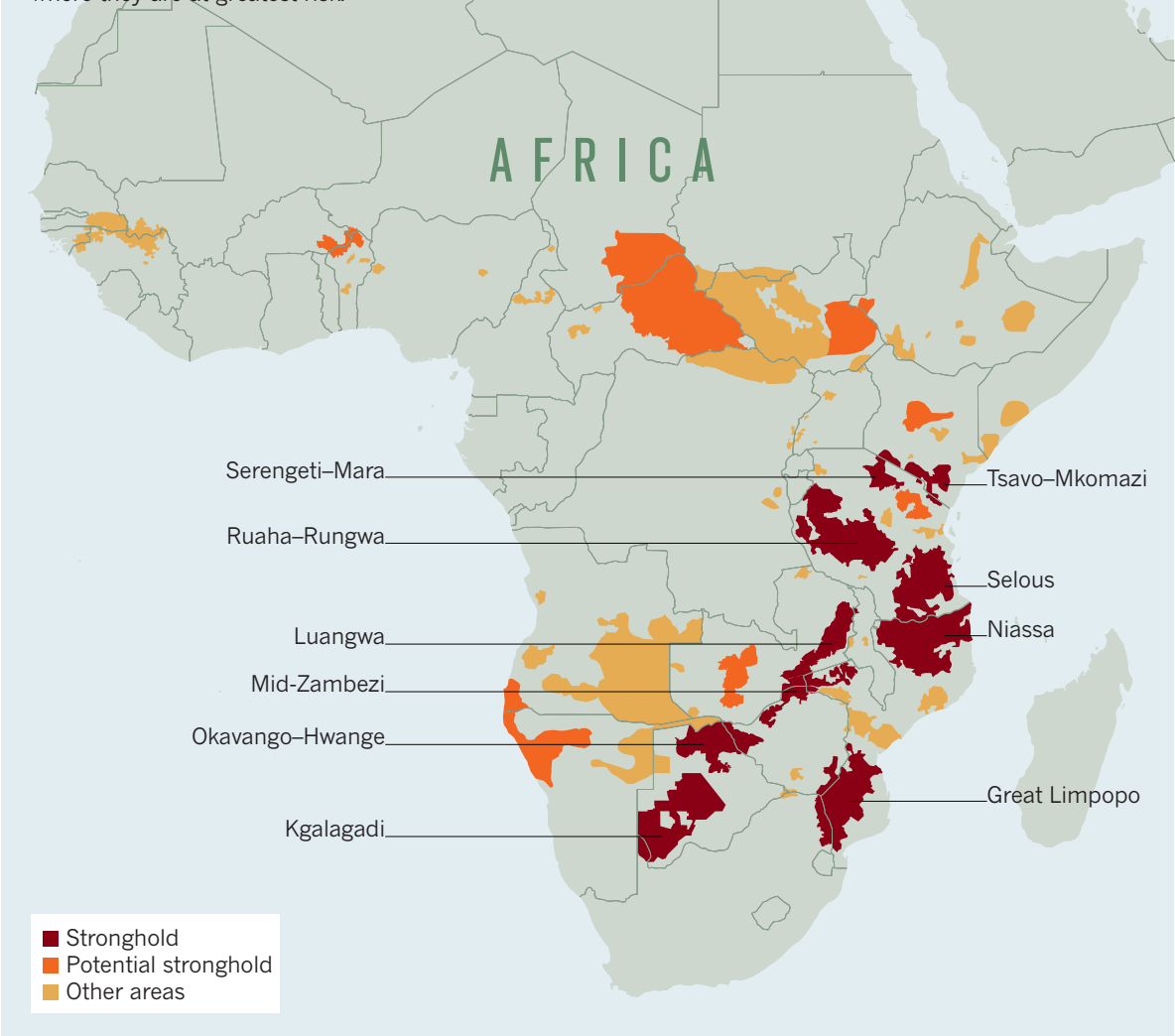

Bush-meat snares made with wire stripped from fences pose another risk. These often catch and may kill lions, elephants and other species, and have been a serious problem in places such as Zambia. But Packer says that a properly built fence, although costly, would not support snaring. And he argues that the opposition's goal of maintaining open landscapes is deeply impractical in the face of Africa's burgeoning human population.

He has already tried to drum up support for fencing with African officials, and he also hopes donors with an interest in conservation projects, such as the World Bank, might fund a fence around a large reserve. Meanwhile, many of those who oppose the idea would rather see money poured into proven approaches such as law enforcement.
But the two camps also share plenty of common ground. Creel's co-authors say that fences can be effective, and Packer's allies agree fences are inappropriate for many areas.

While scientists wrangle over the issue, "lions are disappearing faster than ever", says Philipp Henschel, a lion specialist for the conservation group Panthera, who signed Creel's paper (see 'Grounds for concern'). The community should "concentrate on the one thing that both sides agree on: that effective lion conservation will require substantially more funding than is currently made available".

\footnotetext{
1. Riggio, J. et al. Biodivers. Conserv. 22, 17-35 (2013)

2. Henschel, P. et al. CATnews 52, 34-39 (2010).

3. Packer, C. et al. Ecol. Lett. 16, 635-641 (2013).

4. Creel, S. et al. Ecol. Lett. 16, 1413-e3 (2013).

5. Packer, C. et al. Ecol. Lett. 16, 1414-e4 (2013)
}

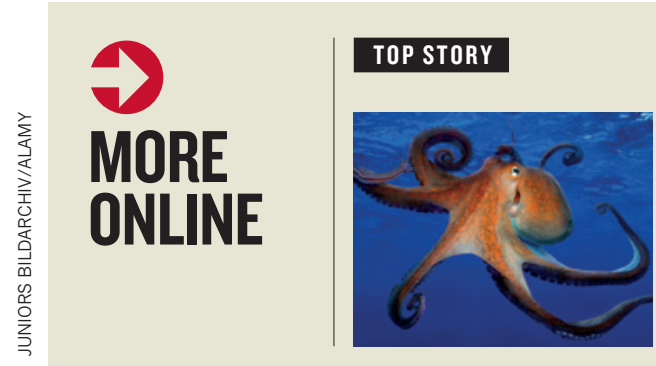

Octopus tentacles have 'a mind' of their own bit. ly/17wsxlz

\section{MORE NEWS}

- Cool laboratories can skew results of cancer studies in mice bit.Iy/17GzfHO

- Bailout for body that oversees animal nomenclature bit.ly/17EFjeC - Lyme pathogens can evolve to evolve bit.ly/1a9JHpS

\section{SLIDESHOW OF THE WEEK}

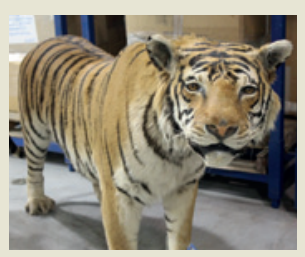

A behindthe-scenes look at goods from illegal trade bit. Iy/Id2IUfj 